Article

\title{
Figuring the Transition from Circular Economy to Circular Society in Australia
}

\author{
Gavin Melles
}

check for

updates

Citation: Melles, G. Figuring the Transition from Circular Economy to Circular Society in Australia. Sustainability 2021, 13, 10601. https:// doi.org/10.3390/su131910601

Academic Editor: Robson Silva Rocha

Received: 26 August 2021

Accepted: 21 September 2021

Published: 24 September 2021

Publisher's Note: MDPI stays neutral with regard to jurisdictional claims in published maps and institutional affiliations.

Copyright: (C) 2021 by the author. Licensee MDPI, Basel, Switzerland. This article is an open access article distributed under the terms and conditions of the Creative Commons Attribution (CC BY) license (https:// creativecommons.org/licenses/by/ $4.0 /)$.
School of Design, Swinburne University, Hawthorn, VIC 3122, Australia; gmelles@swin.edu.au

\begin{abstract}
The combined pressure of economic, environmental, and social crises, including bushfires, waste management, and COVID created conditions for a turn to the circular economy in Australia. In addition to a dominant circular discourse of ecological modernization in state and federal policy and business and public consultations, other more socially inclusive and ecologically sensitive discourses are circulating. The two main competing discourses are a techcentric circular economy and a reformist circular society, the latter reflected in 'growth agnostic' doughnut economics. In the context of unambitious federal and state policies, the circular transition is being supported by a range of intermediary organizations whose key representatives envision or 'figure' the sustainability transition in hybrid discursive combinations. Few studies of the circular economy transition in Australia exist and none focus on competing discourses and intermediation for sustainability transition. Since intermediary organizations both discursively reflect and lead the circular change, fuller understanding of how circularity is interpreted or 'figured' by key actors is crucial. This study identifies how twenty representatives from intermediating organizations actively 'figure' the process of the circular transition for Australia, including while managing the tension between personal positions and organizational missions. Employing the concept of figured worlds this qualitative thematic discourse interview study analyses how, drawing on available circular discourses, key actors and their organisations actively 'figure' the present and future circular transition. The study contributes to debates on circular discourses, nature, and the limitations of the circular economy in Australia, the relational space of intermediation, and the nature of MLP transitions for a sustainable circular transition economy in Australia.
\end{abstract}

Keywords: circular economy; circular society; Australia; sustainability transition; discourses; figured worlds

\section{Introduction: Circular Economies}

Since the original formulation of sustainable circularity for spaceship earth [1], an ecological modernisation (EM) narrative of global green growth has become the dominant global circular discourse [2-5]. EM is an ideal home for circular green growth as it promises sustained growth and consumption through technological advances without radical transformation of the existing economic system [6-12]. With strong precedents in China since the early 2000s [13] and in Europe over more than a decade [14], the green growth circular discourse has belatedly reached Australia as a response to a range of crises [15].

The technicist circular 'umbrella' term [16] and discourse is a 'revived' synthesis of ideas [17] that predate it, including industrial ecology [18], cradle to cradle design [19], and even elements of the sharing economy [20]. The dominant discourse promoted by organisations, such as the Ellen MacArthur Foundation [21], the World Economic Forum [22], the OECD [23] and the European Union [24] is optimistic about decoupling growth from environmental externalities of production and creating increased green consumption. However, mainstream CE leads at best to relative rather than the 'fantasy' of absolute decoupling [25], while social and systemic institutional issues about equitable growth remain un-addressed [26]. Although referred to as a radical paradigm shift [8], 
Campbell-Johnston et al. [27] note that while a mainstream circular economy is often presented as paradigm altering even in leading example cities, such as Amsterdam, there is little evidence of this.

Despite the fact that increased consumption even with material efficiencies is not a strategy to curtail emissions [28] nor deliver on sustainable development [29], global CE champions in finance and business sectors, including the Ellen MacArthur Foundation, welcome increased consumption as a positive outcome of prolonging resource use [30]. McKinsey \& Company 'advise their clients that marketing secondary products, components, and materials in a way that does not cannibalize existing sales' [31] (p. 600) is a win for business. The re-bound effect of increased consumption in secondary markets [31], which is driven by lower prices and higher consumption for refurbished products, e.g., phones [32], is another driver of consumption related emissions that outweigh any butterfly effect of close looped production.

Given that the circular transition remains globally modest at around 9\% [33], the consensus is that mainstream CE will require greater focus on education and other 'soft' initiatives [34], leasing services rather than products [35], designing out waste at the beginning of the production cycle [36], and using digital platforms [37], including circular marketplaces, such as promoted by Circular Economy Hub https: / / www.circulareconomyclub. com/organizations/marketplaces/ (accessed on 12 September 2021). Progress must also overcome lack of consumer interest [38], over-reliance on recycling rather than deeper change [39,40], and lack of control of global supply chain processes and measures [41]. More concerning to many is mainstream $\mathrm{CE}$ failure to consider social equity and distribution and backgrounding of biodiversity and ecological limits [42,43].

\subsection{Circular Economy and Society Discourses}

There is a diversity of interpretations for the 'essentially contested' CE label [44], an ambiguity which some view as no barrier to the catalytic function of CE [30] and others see as evidence for confusion. These and other factors cited are encouraging some to differentiate a mainstream and sustainable circular economy [45,46]. Calisto Friant et al. [47] in particular identify four global circular discourses-a mainstream optimistic technocentric or defensive fortress circular economy, where resources circulate, and two broader reformist and transformational 'radical' circular society discourses (see Table 1 below). These competing discourses uncannily reflect the existing debate to define sustainable development, as in Baker's Ladder of Sustainable Development (Baker, 2013), which differentiates very weak market environmentalism, mainstream ecological modernization, strong sustainable development, and an ideal ecological discourse. The technicist circular economy combines market environmentalism with ecological modernization, while the other discourses take up strong sustainable development (reformist discourse) and ideal ecological discourse (transformational).

Discourses are not only rhetorical devices but have material implications [48], and these circular discourses reflect four visions of the future with consequences for action [49]. The holistic circular society discourses address social justice and ecology and resist or modify the growth imperative [8]. For the technocentric (and fortress) models social and ecological benefits are by-products of growth and consumption and are achieved by decoupling growth from the environment [50]. A technocentric circular economy is the dominant discourse of green growth in business, industry, and government circles.

In current global circular debates, it is the reformist discourse that is most often juxtaposed to the technocentric discourse [51]. Much of this debate is still in media and online sources, and Amsterdam in particular has played a particular role in combining both approaches, e.g., https:/ / time.com/5930093/amsterdam-doughnut-economics / (accessed on 12 September 2021). Note that moves in Doughnut Economics to promote sharing without new consumption is an area where the conflict with a circular economy will be strongest, e.g., https:/ / observer.com/2021/03/circular-doughnut-economics-buyingnothing-new-movement/ (accessed on 12 September 2021). 
Table 1. Circular discourses: Adapted from Friant et al. (2020) and including Baker (2013).

\begin{tabular}{|c|c|c|}
\hline & Holistic & Segmented \\
\hline Optimist & $\begin{array}{l}\text { Reformist circular society } \\
\text { Example: Doughnut Economics } \\
\text { (Strong Sustainable } \\
\text { Development in Baker's Ladder) } \\
\text { Assumptions: reformed form of } \\
\text { capitalism is compatible with } \\
\text { sustainability and socio-technical } \\
\text { innocations can enable } \\
\text { eco-economic decoupling to } \\
\text { prevent ecological collapse. } \\
\text { Goal: economic prosperity and } \\
\text { human well-being within the } \\
\text { biophysical boundaries of } \\
\text { the earth } \\
\text { Means: technological } \\
\text { breakthroughs, social } \\
\text { innovations and new business } \\
\text { models that improve ecological } \\
\text { health, resource security, and } \\
\text { prosperity for all }\end{array}$ & $\begin{array}{l}\text { Technocentric Circular Economy } \\
\text { Example: Mainstream Ellen } \\
\text { MacArthur(Weak or mainstream } \\
\text { sustainable development in } \\
\text { Baker's Ladder) } \\
\text { Assumptions: capitalism is } \\
\text { compatible with sustainability } \\
\text { and technological innovation can } \\
\text { enable eco-economic decoupling } \\
\text { to prevent ecological collapse. } \\
\text { Goal: sustainable human } \\
\text { progress and prosperity without } \\
\text { negative environmental } \\
\text { externalities } \\
\text { Means: Economic innovations, } \\
\text { new business models and } \\
\text { unprecedented breakthroughs in } \\
\text { CE technologies for the closing } \\
\text { of resource loops with optimum } \\
\text { economic value creation }\end{array}$ \\
\hline Sceptical & $\begin{array}{c}\text { Transformational Circular } \\
\text { Society } \\
\text { Example: De-growth } \\
\text { (Ideal 'Green' Sustainable } \\
\text { Development in Baker's Ladder) } \\
\text { Assumptions: capitalism is } \\
\text { incompatible with sustainability } \\
\text { and socio-technical innovation } \\
\text { cannot bring absolute } \\
\text { eco-economic decoupling to } \\
\text { prevent ecological collapse. } \\
\text { Goal: A world of conviviality } \\
\text { and frugal abundance for all, } \\
\text { while faily distributing the } \\
\text { bio-physical resources of } \\
\text { the earth. } \\
\text { Means: complete reconfiguration } \\
\text { of the current socio-political } \\
\text { system and a shift away from } \\
\text { productivistand anthropocentric } \\
\text { world views to drastically reduce } \\
\text { humanity's ecological footprint } \\
\text { and ensure that everyone can } \\
\text { live meaningfully, and in } \\
\text { harmony with the earth }\end{array}$ & $\begin{array}{c}\text { Fortress Circular Society } \\
\text { Example: Business as Usual? } \\
\text { (Market environmentalism in } \\
\text { Baker's Ladder is close but no } \\
\text { equivalent) } \\
\text { Assumption: There is no } \\
\text { alternative to capitalism and } \\
\text { socio-technical innovation } \\
\text { cannot bring absolute } \\
\text { eco-economic decoupling to } \\
\text { prevent ecological collapse } \\
\text { Goal: Maintain geostrategic } \\
\text { resource security and earth } \\
\text { system stability in global } \\
\text { conditions where widespread } \\
\text { resource scarcity and human } \\
\text { overpopulation cannot provide } \\
\text { for all. } \\
\text { Means: Innovative technologies } \\
\text { and business models, combined } \\
\text { with rationalized business use, } \\
\text { imposed frugality and strict } \\
\text { migration and } \\
\text { population controls }\end{array}$ \\
\hline
\end{tabular}

Reformist circular society discourse as reflected in new economy thinking on prosperity [52] has been reformulated recently in Kate Raworth's doughnut economics model [53]. Raworth acknowledges the potential of CE for a new economy but relativizes its material focus, market mechanisms, consumption effects, and questioning decoupling. This is an optimistic model about reforming capitalism that is 'agnostic' about GDP growth since it is focused on well-being. DE acknowledges market, household, government, and the commons as core economic institutions for the environment [54], promotes collaborative social logics and ethics, resists utility maximising homos oeconomicus as an adequate cliché for society, and addresses the 'secondary' social and ecological effects of GDP growth as primary considerations. This reformist DE is an approach which has had impact across the $\mathrm{C} 40$ thriving 
cities initiative (see https: / / www.circle-economy.com/resources/creating-city-portraits (accessed on 12 September 2021)), as also reported in Time Magazine [55].

Transformational circular society meanwhile is a strongly ecological and social discourse that is sceptical of capitalism—reformed or not-, takes a strong approach to limits to growth [56], and looks to a reconfiguration of the current socio-political system. This is the 'ideal' strongly ecological model of sustainable development as described by Baker and consistent with the de-growth and related (very) strong sustainable development movements [57]. Given its rejection of growth it stands in direct opposition to the techcentric circular economy [58]. While growth agnosticism and reformist new economy thinking has limited appeal for business and industry, it is beginning to have an echo in city and local government circles globally, especially in the C40 Thriving Cities initiative, e.g., Amsterdam [59]. Thus, in this study we see four possible circular discourse configurations, future imaginaries [49], visions [47], or portraits [60] rather than one; the three technocentric, reformist, and transformational discourses are represented in Australia.

\subsection{Circularities for Sustainability Transition}

Although the mainstream circular economy presents itself as sufficiently encompassing to be all that is required for a sustainability transition, the existence of multiple discourses around this idea troubles it. In addition, the fact that no circular transition is an end in itself but a means to an end, versions of circularity are paths to sustainability transitions and sustainable development.

Sustainability transitions (see Figure 1 below) are goal-oriented rather than emergent processes in complex environments [61], address public goods, e.g., the environment, and there is debate about the merit of particular solutions [62]. Geels [63-65] argues that the multi-level perspective (MLP) on sustainability transitions highlights the multi-level and multi-actor nature of socio-technical regime change and acknowledges the need to enhance MLP with theories of agency and governance issues [66] to account for how transition can happen [67]. As Baker [68] notes, the governance of sustainable development has in general moved from state-led approaches to multi-level and multi-sector governance networks. Such a focus implies that agency is distributed across and between networked organisations.

Coalitions and networks of research organisations, government and non-government actors, consultancies, and niche actors with an explicit goal to promote $\mathrm{CE}$ typify current circular initiatives in Australia. Niche innovations in protected spaces, e.g., circular labs, marketplaces, and social enterprises, help enrol and grow social networks that meet the political goals and expectations of external influences, such as government and business focus on growth. These processes are reinforced by new, e.g., policy-driven, initiatives towards what Geels calls a 'dominant design'. Examples of existing niche innovations include urban farming, decentralised renewable energy systems, sustainable urban transport, and access and social economies. Political expectations and a growing convergence on a reformist agenda determine which niches, networks, and ideas become mainstreamed and which remain on the margins [69].

The importance of the MLP transition framework is that it identifies typical contextual and dynamic forces driving change as in Australia. Its weakness is that is implies that the new 'dynamically stable' regime emerging from change is singular, whereas any regime is merely one among competing visions or discourses. Hence, intermediation by organisations and individuals is respectively about alignment with different transition visions, such alignment might differ from an organizational and a personal position, and in interview settings interview narrative may move been discourses. 
Increasing structuration of activities in local practices

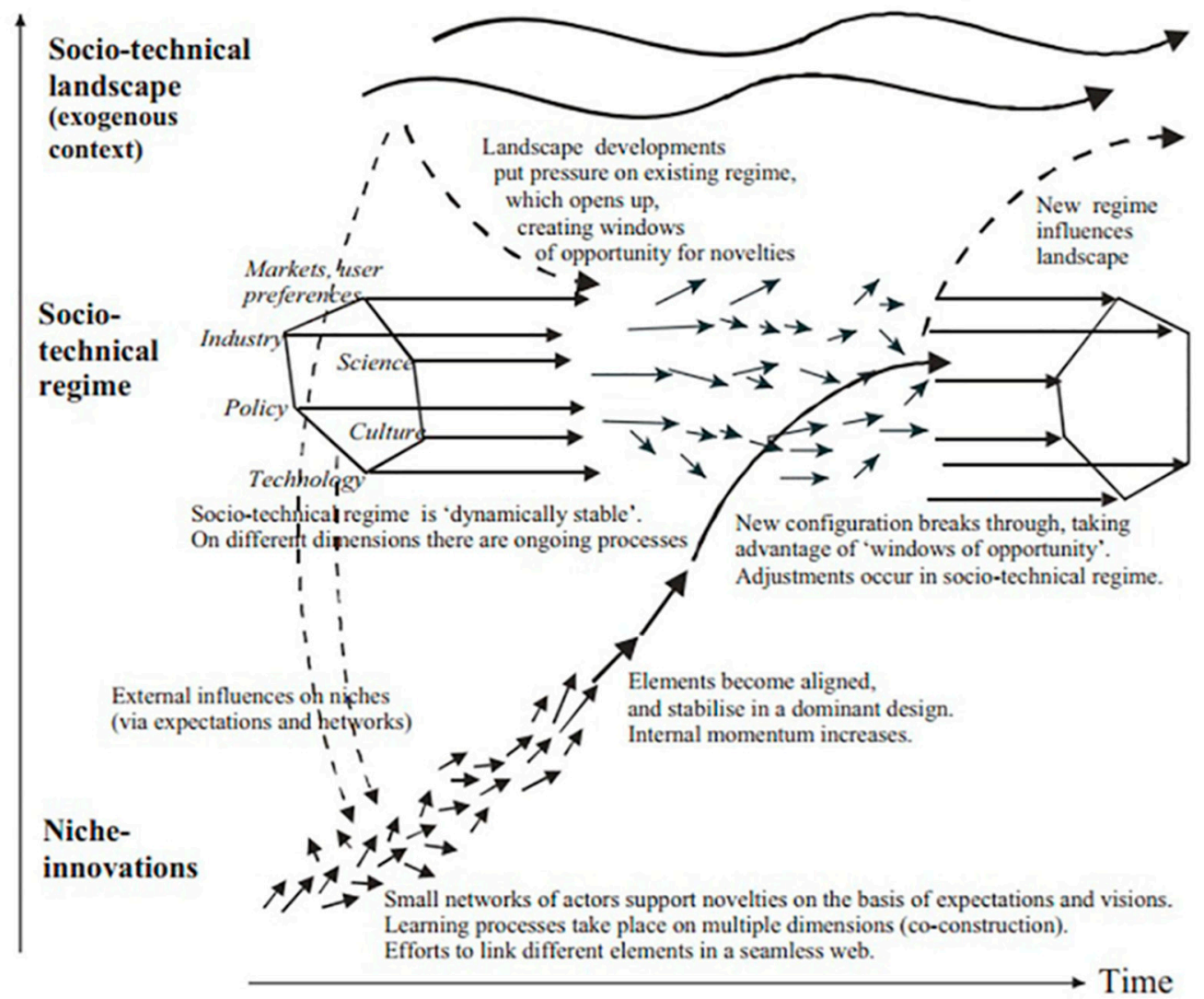

Figure 1. Sustainability transitions theory (following Geels 2011). This photo by unknown author is licensed under CC BY.

\subsection{The Rise of the Circular Economy and Circular Society in Australia}

Circular policy and initiatives form part of the context for systemic transitions and are suffused with political agendas that enable and limit action [70], including and potentially excluding certain actors [71]. In Australia the emergence and current enthusiasm for and mainstreaming of a technocentric circular economy in Australia as a result of external and internal drivers reflects well the MLP transition framework.

Identifiable exogenous pressures—climate change consequences, e.g., severe bushfires [72], COVID pandemic disruption, a long-standing landfill, recycling, and waste management crisis [73-76], which a China National Sword Policy rejecting further offshoring of waste especially in Asia [77] —added fuel to lead to a belated policy flurry responding to socio-economic crises and discourses $[15,78,79]$.

Following a national waste management policy and action plan which alluded to circular economy principles [80], a rash of state level circular policy and national R\&D statements and initiatives on waste management, recycling, and landfill restating the techcentric circular economy discourse of EMF, WEF, etc., followed [72,81-84]. Evidence for a conservative political approach was reflected in the gap between the 'circular economy' titles of public consultations and reports $[81,85-87]$ versus federal and state policies which deliberately backgrounded the term circular economy. Commentators suggested that policy did nothing to solve the ad hoc approach of states and other jurisdictions to manage waste [83], while others suggested the focus needed to be on market creation and not on 'end-of-pipe' solutions [88].

The global promise of circular jobs, continued growth, and new markets, repeated in federal and state policy, was supported by reports predicting large GDP and consumption boosts. KPMG, for example, in collaboration with the national science agency CSIRO 
report on the $\$ 23$ billion GDP boost to the economy as the circular economy payoff [89], while PWC suggests the CE 'revolution' could be worth $\$ 2$ trillion [90]. Repeating these claims, the national R\&D agency CSIRO also produced a 'roadmap to unlock future growth' focused on specific materials, i.e., plastics, tires, paper, and glass [91]. However, none of these claims foreground ecological and social considerations (beyond employment) of circular society needs.

In the absence of strong federal ambitions, it was left to individual states and other organisations to spell out the detail of a circular economy future. Thus, South Australia (SA) took the lead in 2017 publishing a consultation report foregrounding circular economy [86] and integrating CE into state strategy for 2018-2023 with strong packaging, waste, and recycling themes [92]. NSW followed suit with a discussion paper on waste and a Circular Policy Statement [93]. Recently the government supported NSW Circular Platform has released its report on the potential benefits of a circular economy, which although focussed largely on economic benefits alludes to the environment [94]. Queensland released a waste management and resource recovery policy with allusion to a circular economy, and then an outsourced report spelled out in more detail, based on EU precedents, how a future circular economy could be realised in the state [87]. Other states, including the ACT [85] and most recently Western Australia, have released consultations regarding CE and waste [95]. As noted above, these consultation and policy reports repeat the promises of the techcentric discourse.

The federal and state policy and recent funding initiatives have led to the emergence of national hubs, consultancies, and digital platforms of various kinds, such as the ASPIRE online marketplace and similar [75]—developed in collaboration with CSIRO—, for sharing waste resources among businesses, have also emerged as accelerators of CE in Australia. Major retail companies are signing up to the circular agenda, including Target, and the university sector has also begun to develop hubs in collaboration with government and industry centred on specific issues within the circular economy, including Deakin University's CE initiative, RMIT University's Circular Economy Hub and others. In addition, local and regional government have appointed individuals to intermediate and promote the circular economy discourse in their jurisdictions.

Although currently there is limited political or business appetite for reformist and transformational goals for growth and the economy, the success of doughnut economics globally has led to interest and initiatives in Australia. The most salient output of DE in Australia to date is the Melbourne City Portrait [96] developed by the Regen Melbourne coalition, with funding from the Lord Mayor Charitable Fund. The Melbourne report builds on the prior success of the city of Amsterdam, which sought to 'enrich' CE with the broader DE message of 'measures needed to make the city more social and liveable in all respects' [59]. At the time of writing (August 2021) consultations are currently underway in Brisbane (QLD) and Sydney (NSW) for similar 'regenerative cities' portraits and initiatives.

Although both CE and DE have been described by some as reformist discourses, there are fundamental differences in terms of emphasis on growth, decoupling, the market and social distribution. Through the $\mathrm{C} 40$ thriving cities initiative and leading examples such as Amsterdam, the compatibility of the DE and CE agenda is being demonstrated. In fact, DE may offer a broad sustainable development agenda within which CE may play a role. In fact, given the potential conflict between a market-based growth oriented eco-efficiency framework $[97,98]$ and a growth-agnostic multi-institutional model of an embedded economy where the market is only one of several components, the desire to see complementarity is a way of avoiding conflict.

\subsection{Intermediaries in Sustainability Transitions}

Intermediaries for low-carbon and sustainability transitions are 'strategic' actor groups and organisations of various kinds e.g., architects [99], 'choreographing' different forms of trust [100] between supply and demand side elements at niche, regime, and system-wide levels of intervention [101]. Intermediaries have various agendas, such as connecting 
business and industry with research institutions [102-105]. In addition to face-to-face, intermediaries operate through digital platforms of various kinds [37,102,106-108] and vary in their power to effect change [109].

Whatever particular circular discourse dominates in Australia will depend on 'locally embedded' intermediaries facilitating, configuring, and brokering [110] exchange between community, government, and other organisations in a relational space of connections [111]. Thus, a feature of intermediaries is their 'in-betweenness' in being embedded in and connecting between 'spaces' of interaction [112], which are always under construction and typified by diverse even oppositional politics, e.g., within not just across organisations [113]. The relational practice of intermediation is also personally under construction, such that representatives of such organisations must manage their professional role and personal identity [114].

Excluding direct economic actors, e.g., business, industry, and federal and state government, this study treats organisations and their representatives, who have an avowed agenda to mediate and promote circular economy in business and industry, as intermediaries. Thus, research and government and non-government advisory and consulting agencies, e.g., CSIRO, NSW Circular, Sustainability Victoria, and Circular ISO standards network, are the main actors and disseminate advice and reports. Local government bodies (LGAs) and regional organizations appoint individuals to lead circular economy initiatives, e.g., workshops and funding initiatives. Regional level networks of waste management, recovery, and recycling and economic development network with specific universities, consultancies, and local government organizations. Consistent with qualitative case study logic, three cases-the Brisbane Tool Library, the Biggest Garage Sale circular social enterprise 'precinct', and a private circular supply chain consultant-were included deliberately as extreme cases [115] of organisations outside the typical government and non-government bodies. Finally, non-governmental organizations, such as Circular Economy Victoria (CEV), Loop Circular Economy, and Regen Melbourne, are facilitators of change networking with government, business, and civil society implement circular change. Other actors such as digital marketplaces also network and promote intermediate change.

\section{This Study}

This study focuses on the actively figured world(s) of circularity, which intermediary representatives articulate in qualitative interviews relative to available circular discourses. These key institutions include all the organizations that actively promote the elements that constitute the current socio-technical regime and the broader landscape of change. The focus of this study is on circular society visions in Australia. Elements of the more 'radical' deep green transformational circular society discourse exist, including on the margins of the reformist account, while the politically conservative and highly defensive 'fortress circular economy' discourse, although potentially present in Australia, has to date played no key role in current debates.

\section{Interview Methodology and Analysis}

Constructivist oriented qualitative research treats interviews as co-constructed [116-120]. Among constructivist methodologies for interviews, active interviewing has long drawn attention to the consequences of the interactional production of data and analysis where both the topic (the 'what') and the nature (the 'how') of its production are in focus [121]. As with Silverman [122], constructivist approaches treat narrative [123], identity [124], role [125], facts [126], and shared cultural worlds or repertoires [127] not as pre-determined but as discursively reproduced. In responding to questions, respondents will draw on a range of resources to account for, justify, and legitimate their responses [128]. As a result, individuals take a variety of subject positions in interviews, e.g., organisational role, consumer, personal [129], and depending on the topic and position may produce 'so-called' contradictions [130]. 
The constructivist impulse also encourages the search for links between contextual language use and society [131], which is where the notion of a figured world in interviews is fruitful. Figured worlds (FW) was first clearly articulated by Holland et al. [132] as 'as-if worlds where particular characters and actors are recognized, significance is assigned to certain acts, and particular outcomes are valued over others' [132] (p. 41). FW surface in interaction as part identity making in cultural settings such as the transition from personal to institutional identities. Similar to repertoires and cultural models, FW are an interactive category which derive from and respond to more abstract discourse [133] and are 'a route of acceptance or resistance to dominant discourses' [134] (p. 108).

Thus, in this interview study the representation of circular discourses by representatives of intermediary organisations is achieved through particular personal and organizational figured worlds relative to four existing discourses. Balancing personal and organisational identities, these circular figured worlds describe the complex relational spaces of intermediation connecting organisations in various political, economic, and social spaces.

\section{Methodology: Qualitative Interview Recruitment and Thematic Analysis}

Consistent with the theoretical focus on the nature of intermediation for sustainability transition, this study cohort was a purposive sampling of organisations [135] (p. 418). Through the author's networks, snowball suggestions from others, and a search of LinkedIn ${ }^{\mathrm{TM}}$, I identified individuals working for key government, non-government, e.g., research organisations and consultancies, and civil society organizations tasked with promoting the circular economy and doughnut economics (see Table 2 below). The interview cohort included individuals directly involved in writing state level consultancy reports, research, and advisory roles, but also community-level organisations concerned with change. This led to a 'purposeful' recruitment of individuals $(n=20)$ from a range of organisations in the government, research, and non-governmental sectors. Following informed consent and interview outlines these individuals took part in Zoom-based interviews ranging in length from 20 to $45 \mathrm{~min}$. Many individuals had multiple concurrent roles in research, consultancy, and advocacy organisations although one primary role is listed below. Close analysis of LinkedIn connections also identified how the interview cohort were networked with each other [136].

Table 2. Recruitment cohort.

\begin{tabular}{ccc}
\hline Interviewee (Primary) Organisation & (min, s) & $\#$ \\
\hline Circular BCorp Precinct (and Social Enterprise) & 33.27 & 14 \\
\hline Senior Project Officer Economy \& Innovation for LGA & 30.14 & 30 \\
\hline Convenor Regen Melbourne Network & 29.55 & 22 \\
\hline Circular Economy Supply Chain and Business Strategy & 35.24 & 21 \\
\hline Circular strategic design consultancy & 26.09 & 18 \\
\hline Lord Mayor Charitable Foundation & 49.09 & 11 \\
\hline NSW Circular Leader & 21.02 & 16 \\
\hline Regional Program Manager NSW & 27.49 & 10 \\
\hline CEO of Circular Economy Platform, VIC & 26.45 & 17 \\
\hline Member of Circular Economy ISO Committee & 33.51 & 15 \\
\hline Circular Economy Consultant, Speaker and Researcher & 27.21 & 13 \\
\hline Circular Economy \& Business Innovation for Govt. Agency & 26.48 & 29 \\
\hline Circular Economy City Partnership Coordinator & 38.15 & 28 \\
\hline
\end{tabular}


Table 2. Cont.

\begin{tabular}{ccc}
\hline Interviewee (Primary) Organisation & (min, s) & $\#$ \\
\hline Senior Officer for Economic Development for LGA & 22.30 & 23 \\
\hline Founder City Tool Library, Degrowth advocate & 20.45 & 3 \\
\hline Circular Economy Lead at LGA NSW & 41.59 & 24 \\
\hline Regional Lead for Waste and Resource Recovery & 28.07 & 2 \\
\hline Circular Economy Coordinator for Regional LGA & 26.35 & 25 \\
\hline National Circular Economy Platform Manager (Nell) & 29.02 & 7 \\
\hline National R\&D Agency CSIRO & 26.45 & 27 \\
\hline
\end{tabular}

\section{Results: Thematic Analysis}

Thematic discourse analysis as employed here is focused on identifying the key elements of the interactively figured worlds of circular sustainability transition as employed by interviewees [137]. The broadest theme headings, e.g., circular meanings and discourses, are labels for figured world elements. Links to an individual either cited or paraphrased is used as evidence for a more general interpretation of an FW element. Narrative reduction to themes means that some detailed nuances of figured worlds (relative to the discourses above) here cannot be adequately addressed.

\subsection{Australia's Circular Ambitions in Global Context}

Five of the respondents $(13,15,16,24,25)$ had direct experience of the technicist and reformist discourses and practices in the UK and Europe, where the circular economy was a mainstream discourse.

"The circular economy is becoming so much part of the fabric of the EU mechanisms for doing business and doing sustainable business and doing bioeconomy that it's just background noise. Whereas here there's no background noise here yet" (24)

Comparisons were made about the belated engagement of Australia with circularity compared to the 'more mature conversation' in Europe (25).

"Usually what happens is that after about 10 years of the Europeans playing around in those spaces, it seems, to maybe even 20 years. It seems to trickle down to Australia and we say oh that's a good idea. Let's try and be late mover advantage here" (10)

Compared to political discussions in Europe about a just and sustainable society, funded collaboration between EU countries, existing implementation of Circular ISO standards, and bioeconomy hubs in Ireland, Australia had yet to make significant progress. However, some viewed the circular moment as an opportunity for Australia, e.g., with its solar renewable potential, to leapfrog other countries, an argument recently made by Garnaut [138]. In many ways, the recent rash of state, regional, and local government level circular economy policy and funding, albeit narrowly conceived, and the establishment of public and private circular innovation agencies and platforms aims to replicate this prior experience in Europe.

Slow global progress of the circular economy was acknowledged, as well as the limited influence of Australia on global systems of production. However, value and supply chain relationships with key regional partners, especially China, e.g., in recycled steel, would be transformed if technical circularity was implemented. This change might also enable better product stewardship and sustainable supply chains - two elements referred to in policy and by over half the respondents. Thus, although Australia was a latecomer to transition, for some interviewees this held potential for Australia to 'leap frog' innovatoin here compared to Europe, albeit only in a context of political change. 


\subsection{Figuring Multiple Circular Meanings and Economy and Society Discourses}

Although organisations articulate narratives consistent with the circular discourses above through their policy, consultation, and other documents, the individuals who represent them 'figure' accounts combining elements from multiple discourses. Thus, figuring circularity as a way of making waste have a 'cleaner more palatable feeling' (14), promoting local economies, and developing regenerative economies shows figured combinations among discourses in individual interview narratives. This is a core difference about relatively coherent organisational discourse versus actively 'figured worlds', which as noted above is a discursive space of agency.

Those with experience in related areas are aware that recent circular economy and society definitions are historically not new and contrast this 'fact' with statements by those who have recently adopted the techcentric and reformist discourses (15). In general, there is acknowledgement of the potential ambiguities of the 'quite amorphous' (25) circular umbrella term and related practices, including the danger of it having become another 'useless' greenwashing term (3), which is 'a not entirely robust take on sustainability' (25). Definitions and terms need to adapt to relevant audiences, i.e., business, society, government, because the 'figured' visions of a circular economy, e.g., the Butterfly image of EMF, are 'quite complicated for people' (27).

Despite variation in experiences, all interviewees are aware of circular economy mottos, including allusions to linear versus circular, decoupling growth from resource use $(03,22)$, keeping materials in circulation (23), regenerative cradle to cradle design principles (11), waste as input, and focus on supply chains. Relative to these 'reductionist' (22) definitions and discursive claims, they express degrees of scepticism about their practical outcomes. Thus, aspects of other discourses, e.g., the regeneration of natural systems (29), connection of livelihoods and resilience to environmental circumstances (11) or 'just describing an Earth system in its beautiful simplicity' (28), are cited.

While there is often appeal to the systemic nature of a circular economy, which 'could be everywhere' (2) even as 'a better post-consumer management' (3) of resources, not everyone is convinced that the economy discourse is 'underpinned by systems thinking' (18) except within the limitations of the technical closed loop narrative. Individuals appeal to the systemic 'radical' nature of the discourse while elsewhere emphasizing it as a tool which 'dabbles in the lower levels of the product level' or similar (22), to create a broader circular society change. The distinction between the circular economy as a tool rather than the tool for radical systemic change recurs throughout the interviews even for those who question the need for a distinction between economy and society discourses.

There is a concern for the need to move beyond limited 'semicircular' solutions (10), which do not threaten the status quo of business and industry and centre on material and capital efficiencies, waste management, and recycling. In particular, practice and initiatives remaining at the level of a recycling economy is acknowledged as a danger, reinforced by narrow state and federal policy. This is a danger that needs to be constantly challenged (13) and is exacerbated by narrow policy definitions and business and industry inertia. Since a circular economy should not be 'just a synonym of recycling' (3) and is 'an issue of the economy' (16) rather than waste, everyone recognizes that narrow technical definitions and practices focused on goods and services alone (15) will not succeed in promoting change.

Despite these dangers and definitional issues, pragmatic attitudes to the value of a circular economy as a way of reengaging industry is strong. Everyone repeats the message of the circular economy being a way of not only addressing sustainability in an era of climate change (23) but of reconnecting sustainability with a disengaged business, manufacturing, and industry sector. However, since the circular economy is 'not explicitly challenging the growth narrative' (22) and in fact promoting green consumption, most recognise that it may not turn the carbon emissions trajectory down.

The dominate techcentric circular economy narrative as belatedly adopted by Australia is reinforced in federal and state policy and media, focused narrowly on waste management and recycling, and figured as a useful re-engagement narrative for business 
and industry, albeit long-term limiting and a potential source of greenwashing. There is explicit discussion in the interviews of three of the four discourses with the reformist and techcentric contrast dominating comparisons. The consequences for intermediation are that agency for change must tread a difficult mid-way between encouraging short-term business and industry engagement and promoting deeper change steps with a reformist and even transformational agenda.

\subsection{Figuring the Circular Economy and Society Discourse Relationships \\ "Like I mean circular economy is-it's very hard to relate circular economy and it does it injustice if you try to solve things like gender equality. or you know, like housing, like social housing." (17)}

Although a number of those with recent local and regional government roles admitted to limited understanding of the detail of DE, the interview asked for contrasts between circular society, e.g., doughnut, and economy as discourses in Australia for having 'agency to effect change' (7). This discussion also surfaced elements of the circular transformation discourse, especially for de-growth movement advocates (3, and partly 11).

For most, circular economy is 'a body of knowledge' that might enable a broader society paradigm shift (17) and could 'enable that different kind of systems level thinking' (22) associated with circular society. Compared to the technical narrative of the circular economy, one interviewee noted that doughnut by comparison 'empowers people with no economic background to have an opinion' (11). Overall, three broad positions prevailed: doughnut economics as the more encompassing socio-ecological and economic framework for the techcentric circular economy tool; doughnut economics as distinctive and deeper than the narrow focus of the circular economy; and discursive contrasts as somewhat flawed, marginally relevant, or even unnecessary; these contrasting framings could be figured simultaneously by interviewees.

There was general agreement, albeit with nuances about doughnut economics as a broader strategy or 'non-prescriptive' (11) frame for circular economy tools. Many commented on the doughnut image as a 'really great way of framing' (23) an old idea-a circular society-although it was generally agreed that doughnut economics did not resonate with business and politicians, although it was beginning to with local government-but only through a circular society implementation would technical circularity be ethical and just. In this figured world the circular society agenda could

"leverage the discussion around and the opportunities seen around circular economy to go a step further beyond a very iterative softly softly reformative approach, which is not going to do the trick because it's still embedded in the current approach to business." (25)

Despite a few attempts to negate or minimise any difference, for most the doughnut presents a 'more encompassing' (22), more 'inclusive' (18) new economics based around markets, commons, government, and households, which is focused on a growth agnostic 'thriving' (17), especially in cities (21), and humans as not just 'self-serving economic rationalist creatures' (22). All individuals in this interview cohort had degrees of familiarity with or commitment to DE as an expanded agenda for change in Australia and recognized that this was another area where Australia was 'way behind countries that are now implementing doughnut economics' (16). The advantage of this 'flexible' narrative has disadvantages in terms of measurability relative to $C E$ and appeal to business and industry as the key agents of change. Circular economy, despite the name, promotes mainstream 'green' growth and at best 'supply chain' focused (27) change while DE challenges the 'old school capitalist narrative' (28).

One respondent with a strong history in Europe and agenda in Australia to promote a circular economy (13) suggested the distinction was of limited value since 'circular' had various deep and surface interpretations. Another related claim was that despite discursive difference the overall change was important and the labels were not (22), while an advocate of de-growth simply suggested DE was insufficiently transformational (3). 
Thus, parallel discussion of the merits of DE is emerging, with its most palpable form to date in the Melbourne city portrait project. That said, the relevance of such social and ecological considerations for a 'well-off country' (2) like Australia was questioned in thinking about the penetration of DE. Thus, there was a clear consensus on the relevance of a hierarchy of discourses with circular society encompassing a circular economy and an evaluation of the narrow and potentially superficial nature of the techcentric discourse relative to sustainable change. There was a hope that in a few 'years' time the two CE and DE concepts would be more widely kind of understood and recognized' (29).

\subsection{Figuring Institutional Intermediation}

This study explicitly recruited individuals from a diversity of organizations promoting sustainability transitions at niche and higher levels who were aware of the circular economy and society discourses, albeit to varying extents. Conventional treatments of intermediation portray relatively homogenous entities connecting with different sector actors. This study treats intermediation as a complex relational space, including for individuals and within organizations not only between them.

Some like the Biggest Garage Sale end to end B2B and B2C enterprise were creating new markets through a closed loop circular 'capture' of business waste streams, including defective products of large retailers, with potential for direct conversion to new products-described as 'minimal transformation for maximum value' and focused on 'shared economic value' rather than market domination. Others like the Brisbane Tool Library were focused on the sharing economy value and social networks connecting levels of government and community and on a circular transformation de-growth narrative. Non-governmental platforms at state level such as Circular Economy Victoria networked with government, universities, and other actors to focus on the social innovation and frameworks required for both the technicist and circular society ambitions. Within these (and other organisations) are a variety of positions on the various circular discourses which individuals try to balance with the organizational agenda.

Individuals distinguished their personal and professional (organisational) positions relative to questions, and such 'identity work' is well established in organisational research studies (e.g., Watson, 2008). Thus, personal scepticism about the claims of CE (or DE) were distinguished from the organisational discourse and mission; this distinction forms part of the agency of discourse figuring. Organizational intermediation is achieved by people who must navigate the personal and professional space of intermediation, especially in government or consultancy positions.

Naturally the different functions of organisations as intermediaries not only between but also within businesses, government, consumers, and society creates specifics of intermediation. Thus, some respondents described their role as not only reaching outward into their local environment of action but within their organization, including local government:

"I'm making it my role within Council to really bring together different parts of the organization around the circular economy because as you know, it's very much about working with a range of people". (23)

Thus, the de-growth-oriented respondent leading the sharing economy Brisbane Tool Library describes their organization as a 'niche bubble about social structures' connecting state and local government (03), while a circular precinct with social enterprise aims capturing business product waste streams and converting them into closed loop product outputs creates a 'transformational shopping centre experience' (14). A strategic design consultancy in a conservative political climate in WA helps organisations transition to circularity while a national platform-Planet Ark-seeks to make circularity clear to business including through designing tools and roadmaps. The list of specific targets and goals thus vary enormously, but in all cases, there are networking, education, tool, market making, and reporting activities with state-wide, local, and even national ambitions.

Some of these organisations depend on federal and state funding 'buckets' while others are engaged directly in creating new markets and supply chain possibilities. Research 
organisations, such as CSIRO and universities, collaborating with 'citizen' platforms, such as CEV Victoria and NSW Circular, government, and business deliver 'independent' reports on the way forward, while national circular ISO standards and related activities help lay the regulatory framework for product stewardship and other aspects. There is some critique among respondents of the limits of funding and the narrow agendas of government and business in an environment where innovation in market creation, supply chains, and overall economic transformation is urgent. As indicated by the sustainability transformation framework, digital marketplaces, material innovations, new closed loop circular precincts, and other innovations will collectively only lead to an incremental but not a radical transition of the political, social, and economic environment.

For those in regional and local government roles, networking across multiple groups is central to their designated or self-appointed role as circular promoters. In many cases, appointment to such roles from other positions in related sustainability, economic development, or waste management areas requires quick catch up to become for example 'an expert over the last 18 months' (10) in circular economics as regional mayors decide this is a new focus. For a major city philanthropic organization, the ever-changing environmental and economic inequality challenges feed into specific micro-challenges that must be met, including through adopting both circular economy and circular society discourses. In other cases, including for research and advisor roles, appointment has been based on long prior experience and knowledge including through study and research.

\subsection{Federal and State Policy and Local Action}

As noted above, the circular discourses emerged and developed in specific historical and geographic contexts, especially in the EU and China, and are compared and contrasted with Australia's more recent adoption of $\mathrm{CE}$, mostly in terms of tensions between federal and state framing of the status quo versus local ideas and practices. The ongoing struggles to mainstream the term circular economy with business and the political sector is cited as one reason for a narrow agenda and also the lack of engagement with more 'radical' circular society discourses. Thus, there was a general scepticism of state and federal policy albeit with leadership in some states-South Australia-but belief in the power of local initiative and hope for future regime change, which could build on the current waste and recycling focus to create sector, regional, and local level change.

More enlightened leadership stretched also to a Victorian state treasurer referring to elements of the reformist discourse in 'talking about well-being economy' (11). In contrast, Western Australia's circular discussion document was characterized as weak and containing retrofitted circular ideas, while opinion was divided on the NSW Policy, which still had to 'tackle these big policy reform issues' (16). On the one hand, consultation documents and reports had a broader palette of ideas than just waste and recycling, while state policy was according to one respondent lead by waste with 'no real hard targets of hard objectives' provided in a 'fluffy' document (15). Thus, the disappointment with federal policy contrasted with more hopeful accounts of state level leadership.

"So I've gone through a bit of a cycle in my reaction to it as everyone else. I was when I read through and participated in some of the webinars and understood what it was it was a big disappointment that it started with recycling"

Those with access to the new state funding incentives see these as a way of getting started:

"I think it's a good place to start because there's funding there's money in waste. It's so sometimes you got to follow the money to get off the ground. So we're you know, we're using waste grants to run our projects. So that makes perfect sense to start there" (10)

This narrow framing of the status quo is even seen to be out of step with concern in the business and other communities. 
"We're very caught up in our three-year election cycles and all how do I get in next year and keep the business community happy when in fact it's the business community who are going, what the fuck? You know, we can't keep we're undermining ourselves" (24)

While the federal response to circularity and related aspects, e.g., biodiversity and conservation, is criticized, there is more hope and scope expressed in state level policy and practice, especially with respect to the broader circular society vision.

"I think a much more coherent policy framework across departments puts well-being. It's put social and ecological well-being at its heart, which I think we're nearly there nearly there" (11)

While the states provide, by way of their specific policies, funding and other initiatives it is at the local government, regional, and city level that action takes place. This local embedding, as noted above, is the ideal level for promotion of prior and new niche innovations, which collectively can lead to change. At the same time local level action is limited by the state who ultimately provide the regulatory and financial platform for such change. Thus, subsidiarity in governance encourages and limits innovation.

Although even here there were limits evident in a continued focus on recycling, landfill, and waste management rather than innovation, actors at a lower level, e.g., local and regional governments, community organizations, and others, were where the potential for innovative change was possible, although these actors were bound by financial, regulatory, and other political limits established by state and federal actors. Funding emanated from the state or federal government as well as the agenda and so action at the lower level of local intermediation at regional or local government was bound by these limitations. At the two highest levels of government there was no formal recognition of reformist circular discourses. and it is only at the local intermediation level that is the focus in this study that such discourses among community, non-governmental, and some local government organizations that reformist and transformational discourses get any hearing.

Thus, in general, federal and state policies were characterized either as a platform for or an obstacle to real progress and necessarily focused on waste management and recycling in the short term. States varied in the quality of their consultation and policy and potential for reform, and transition was dependent on the political regime and leadership at that level. These figurings of government and policy discourses and practices have direct consequences for the consulting agencies, local and regional government departments, research agencies, non-governmental circular platforms, and other actors here characterized as intermediaries because this is the scope of funding available. Further progress on circular economy and society goals would either develop from this narrow base over time or would require major institutional change.

\subsection{A Sustainable Circular Australia}

One of the interview questions asked interviewees to consider what a future sustainable Australia would look like-an indirect appeal to figure their own vision of what this looked like-and this elicited a variety of visions appealing to deeper green transformational discourses where Australia would 'mimic nature in terms of its broad systems' (17). This was an opportunity not only to express hopes in general but also justifications for any positions taken. This area of the interview also focused on the different institutions, e.g., federal, state, and local government, society, and other broader actors, influencing the likely success of circular transition. The need to overcome consumer and society resistance to and misunderstanding of circular promises, and the high footprint consumption of the nation in general, was both a present and future threat to normalising whatever hybrid technical and social agenda emerged. Similarly, the other main player sectors-business, industry, and manufacturing-were variously painted as resistant to change from the status quo but also anxious for innovation and leadership_-both ideas often combined in one interview at different points. 
Although predicting the future was difficult for some, a number of shared and individual hopes were expressed, spread between both technicist and reformist discourses, including a future in which there was a common language about non-GDP measures, global consensus on emissions reductions, and stronger implementation of circular projects as best cases models. The hope for stronger ties of circular economy and society discourses to government plans at the LGA level is already taking place to some extent with several individuals reporting both technicist and society discourses being discussed in council plans albeit under different names. Acceptance of the Garnaut narrative about a future Australia was one concrete wish which combines both technical and social agendas. Key states, such as Victoria, South Australia, and to some extent NSW, were seen to be future leaders.

\section{Conclusions}

There are global concerns that despite enthusiasm for a circular economy in business and government circles, the approach is being narrowly framed and making little global progress [13-24]. Current evidence suggests that interpretations of circularity have already developed into separate discourses of greater or lesser holism and potential for socioeconomic reform [47]. These discourses are reflected in the formal articulations of key actors, such as waste policy, consultation reports, and other documents. Within organisations, however, more hybrid mixing of discourses and 'figuring' of sustainability transitions is taking place, especially with respect to the technicist and reformist visions.

Under the pressure of a waste management and landfill crisis, Australia recently announced a turn to a circular economy, albeit in narrowly framed federal and state level consultation and policy statements. These and related documents from research, financial, and other agencies reiterate the technicist circular economy discourse while elements of more reformist and transformational ('de-growth') discourses also circulate in other intermediary spaces of sustainability transition. The policies and funding initiatives linked to a circular economy have begun to shape responses to a business and industry transition with a strong focus on waste management, recycling, and other materials focuses.

This paper has suggested that there are competing circular discourses and these are figured in particular ways in interactive contexts. It is in these figurings that the potential for hybrid socially just and ecologically sound circular discourses to emerge and displace current dichotomies can be seen. Intermediary organisations of various kinds 'figure' their circular mission in ways consistent with available circular discourses, including with greater or lesser emphasis on reformist and transformational agendas, such as that spelled out in doughnut economics.

This paper suggests that available circular discourses are reflected in organisational documentation of key circular actors and intermediaries, e.g., waste policy, public consultation, and city portraits, by government, non-government, private, and other organisations. It is discursively hybrid articulations of figured circular worlds that dominate in intermediary spaces at local levels where the 'action' is. These worlds combine elements of technicist, reformist, and transformational discourses in various mixes relative to topical moments in the interview process and the identity positioning of the respondent. In this sense there is no one circular economy transition ahead, but technicist and society discourses about a sustainability transition for Australia that address strong reformist and transformational agendas or weaker versions of business and industry innovation.

Representatives of the complex mix of intermediaries figure their affiliation with and resistance to existing circular discourses in a variety of ways, and these figured circular worlds contain a hybrid mix of such discourses. Interviewees also articulate the potential tension and contrast between personal and organisational principles, the latter where outward facing relations to other government, business, and consumer organisations are spaces where discursive compromise was most necessary.

Compared to existing studies of intermediation for low-carbon transitions [99-109], this study finds a far more complex and 'messy' space of intermediation relative to circular 
discourses [111,112,114]. The challenge of moving sector groups such as consumers and society, business, and government towards deeper circularity is a central concern of this mixed group, and there are regular allusions to the need for political, business, and society leadership to galvanize interest and overcome mental, infrastructure, and other barriers.

Future studies should pay more attention to the complex relational spaces of intermediation for circular transition [115] and the competing circular discourses for a sustainable Australia [47]. Policy and government need multi-level intermediation to shift business and society to a more equitable and just sustainability transition and this should be reflected in official pronouncements [62-65]. Without such a balance the transition will be a closed loop of technical adjustments without potential to achieve change.

Clearly also there is potential for this approach and its focus to be attempted in other countries since intermediation and the existence of multiple circular discourses is a common feature.

Funding: This research received no external funding.

Institutional Review Board Statement: The study was conducted according to the guidelines of the Declaration of Helsinki, and approved by the Swinburne University Human Ethics Committee $(272 / 015$ on $02 / 03 / 21)$.

Informed Consent Statement: Informed consent was obtained from all subjects involved in the study.

Conflicts of Interest: The author declares no conflict of interest.

\section{References}

1. Boulding, K. The Economics of the Coming Spaceship Earth. In Environmental Quality in a Growing Economy; Jarrett, H., Ed.; Resources for the Future/Johns Hopkins University Press: Baltimore, MD, USA, 1966; pp. 3-14.

2. Bailey, I.; Gouldson, A.; Newell, P. Ecological Modernisation and the Governance of Carbon: A Critical Analysis. Antipode 2010, 43, 682-703. [CrossRef]

3. Gibbs, D. Ecological modernisation, regional economic development and regional development agencies. Geoforum 2000, 31, 9-19. [CrossRef]

4. Jänicke, M. Ecological modernisation: New perspectives. J. Clean. Prod. 2008, 16, 557-565. [CrossRef]

5. Spaargaren, G.; Van Vliet, B. Lifestyles, consumption and the environment: The ecological modernization of domestic consumption. Environ. Politics 2000, 9, 37-41. [CrossRef]

6. Christoff, P. Ecological modernisation, ecological modernities. Environ. Politics 1996, 5, 476-500. [CrossRef]

7. Fudge, C.; Rowe, J. Ecological Modernisation as a Framework for Sustainable Development: A Case Study in Sweden. Environ. Plan. A: Econ. Space 2001, 33, 1527-1546. [CrossRef]

8. Hobson, K.; Lynch, N. Diversifying and de-growing the circular economy: Radical social transformation in a resource-scarce world. Futures 2016, 82, 15-25. [CrossRef]

9. Howes, M.; Mckenzie, M.; Gleeson, B.; Gray, R.; Byrne, J.; Daniels, P. Adapting ecological modernisation to the Australian context. J. Integr. Environ. Sci. 2010, 7, 5-21. [CrossRef]

10. Pepper, D. Ecological modernisation or the "Ideal model" of sustainable development? Questions prompted at Europe's periphery. Environ. Politics 1999, 8, 1-34. [CrossRef]

11. York, R.; Rosa, E.A. Key challenges to ecological modernization theory: Institutional Efficacy, Case Study Evidence, Units of Analysis, and the Pace of Eco-Efficiency. Environment 2003, 16, 273-288. [CrossRef]

12. Zhang, L.; Mol, A.P.J.; Sonnenfeld, D.A. The interpretation of ecological modernisation in China. Environ. Politics 2007, 16, 659-668. [CrossRef]

13. Zhao, X. China's Policies for Promoting the Circular Economy: Past-Decade Experiences, Future Plans and Success Stories. In Unmaking Waste in Production and Consumption: Towards the Circular Economy; Crocker, R., Saint, C., Chen, G., Tong, Y., Eds.; Emerald Publishing Limited: Bingley, UK, 2018; pp. 49-66. ISBN 9781787146198.

14. McDowall, W.; Geng, Y.; Huang, B.; Barteková, E.; Bleischwitz, R.; Türkeli, S.; Kemp, R.; Doménech, T. Circular Economy Policies in China and Europe. J. Ind. Ecol. 2017, 21, 651-661. [CrossRef]

15. Levitzke, P.S.M.V. The Development of a Circular Economy in Australia. In Circular Economy: Global Perspective; Khosh, S.K., Ed.; Springer: Singapore, 2020; pp. 25-42. ISBN 9789811510526.

16. Homrich, A.S.; Galvão, G.; Abadia, L.G.; Carvalho, M.M. The circular economy umbrella: Trends and gaps on integrating pathways. J. Clean. Prod. 2018, 175, 525-543. [CrossRef] 
17. Reike, D.; Vermeulen, W.J.V.; Witjes, S. The circular economy: New or Refurbished as CE 3.0?-Exploring Controversies in the Conceptualization of the Circular Economy through a Focus on History and Resource Value Retention Options. Resour. Conserv. Recycl. 2018, 135, 246-264. [CrossRef]

18. Lifset, R.; Graedel, T.E. Industrial Ecology, 2nd ed.; Elsevier: Amsterdam, The Netherlands, 2015; Volume 11, ISBN 9780080970875.

19. McDonough, W.; Braungart, M. Cradle to Cradle: Remaking the Way We Make Things; Farrar, Straus and Giroux: London, UK, 2010; ISBN 1429973846.

20. Allen, D.; Berg, C. The Sharing Economy: How Over-Regulation Could Destroy an Economic Revolution; Institute of Public Affairs: Melbourne, Australia, 2014.

21. EMF. Towards a Circular Economy: Business Rationale for an Accelerated Transition; Ellen MacArthur Foundation: Cowes, UK, 2015; Volume 20.

22. WEF. Circular Economy in Cities: Evolving the Model for a Sustainable Urban Future; White Paper; World Economic Forum: Geneva, Switzerland, 2018.

23. McCarthy, A.; Dellink, R.; Bibas, R. The Macroeconomics of the Circular Economy Transition; OECD Publishing: Paris, France, 2017; Volume 33, pp. 1-50. [CrossRef]

24. EEA. Circular by Design: Products in the Circular Economy; European Environment Agency: København, Denmark, 2017; ISBN 9789292138578.

25. Fletcher, R.; Rammelt, C. Decoupling: A Key Fantasy of the Post-2015 Sustainable Development Agenda. Globalizations 2017, 14, 450-467. [CrossRef]

26. Moreau, V.; Sahakian, M.; van Griethuysen, P.; Vuille, F. Coming Full Circle: Why Social and Institutional Dimensions Matter for the Circular Economy. J. Ind. Ecol. 2017, 21, 497-506. [CrossRef]

27. Campbell-Johnston, K.; ten Cate, J.; Elfering-Petrovic, M.; Gupta, J. City level circular transitions: Barriers and limits in Amsterdam, Utrecht and The Hague. J. Clean. Prod. 2019, 235, 1232-1239. [CrossRef]

28. Crocker, R. From 'Spaceship Earth' to the Circular Economy: The Problem of Consumption. In Unmaking Waste in Production and Consumption: Towards the Circular Economy; Emerald Publishing Limited: Bingley, UK, 2018; pp. 13-33. ISBN 9781787146198.

29. Bengtsson, M.; Alfredsson, E.; Cohen, M.; Lorek, S.; Schroeder, P. Transforming systems of consumption and production for achieving the sustainable development goals: Moving beyond efficiency. Sustain. Sci. 2018, 13, 1533-1547. [CrossRef]

30. Blomsma, F.; Brennan, G. The Emergence of Circular Economy: A New Framing Around Prolonging Resource Productivity. J. Ind. Ecol. 2017, 21, 603-614. [CrossRef]

31. Zink, T.; Geyer, R. Circular Economy Rebound. J. Ind. Ecol. 2017, 21, 593-602. [CrossRef]

32. Dießenbacher, J.; Reller, A. Das „Fairphone“-Ein Impuls in Richtung nachhaltige Elektronik. In Kritische Metalle in der Großen Transformation; Springer: Berlin/Heidelberg, Germany, 2016; pp. 269-292.

33. Platform for Accelerating the Circular Economy (PACE). The Circularity Gap Report 2020: When Circularity Goes from Bad to Worse: The Power of Countries to Change the Game; Circle Economy: Amsterdam, The Netherlands, 2020.

34. Del Mar Alonso-Almeida, M.; Rodríguez-Antón, J.M.; Bagur-Femenías, L.; Perramon, J. Sustainable development and circular economy: The role of institutional promotion on circular consumption and market competitiveness from a multistakeholder engagement approach. Bus. Strateg. Environ. 2020, 29, 2803-2814. [CrossRef]

35. Stahel, W.R. The circular economy. Nature 2016, 531, 435-438. [CrossRef] [PubMed]

36. Andrews, D. The circular economy, design thinking and education for sustainability. Local Econ. 2015, 30, 305-315. [CrossRef]

37. Antikainen, M.; Uusitalo, T.; Kivikytö-Reponen, P. Digitalisation as an Enabler of Circular Economy. Procedia CIRP 2018, 73, 45-49. [CrossRef]

38. Kirchherr, J.; Piscicelli, L.; Bour, R.; Kostense-Smit, E.; Muller, J.; Huibrechtse-Truijens, A.; Hekkert, M. Barriers to the Circular Economy: Evidence From the European Union (EU). Ecol. Econ. 2018, 150, 264-272. [CrossRef]

39. Barreiro-Gen, M.; Lozano, R. How circular is the circular economy? Analysing the implementation of circular economy in organisations. Bus. Strateg. Environ. 2020, 29, 3484-3494. [CrossRef]

40. Fitch-Roy, O.; Benson, D.; Monciardini, D. Going around in circles? Conceptual recycling, patching and policy layering in the EU circular economy package. Environ. Politics 2019, 29, 1-21. [CrossRef]

41. Franco, M.A. A system dynamics approach to product design and business model strategies for the circular economy. J. Clean. Prod. 2019, 241, 118327. [CrossRef]

42. Buchmann-Duck, J.; Beazley, K.F. An urgent call for circular economy advocates to acknowledge its limitations in conserving biodiversity. Sci. Total Environ. 2020, 727, 138602. [CrossRef] [PubMed]

43. Desing, H.; Brunner, D.; Takacs, F.; Nahrath, S.; Frankenberger, K.; Hischier, R. A circular economy within the planetary boundaries: Towards a resource-based, systemic approach. Resour. Conserv. Recycl. 2020, 155, 104673. [CrossRef]

44. Korhonen, J.; Nuur, C.; Feldmann, A.; Birkie, S.E. Circular economy as an essentially contested concept. J. Clean. Prod. 2018, 175, 544-552. [CrossRef]

45. Blum, N.U.; Haupt, M.; Bening, C.R. Why "Circular" doesn't always mean "Sustainable". Resour. Conserv. Recycl. 2020, 162, 105042. [CrossRef]

46. Velenturf, A.P.M.; Purnell, P. Principles for a sustainable circular economy. Sustain. Prod. Consum. 2021, 27, 1437-1457. [CrossRef]

47. Calisto Friant, M.; Vermeulen, W.J.V.; Salomone, R. A typology of circular economy discourses: Navigating the diverse visions of a contested paradigm. Resour. Conserv. Recycl. 2020, 161, 104917. [CrossRef] 
48. Hardy, C.; Thomas, R. Discourse in a Material World. J. Manag. Stud. 2015, 52, 680-696. [CrossRef]

49. De Angelis, R.; Ianulardo, G. Circular Economy as Fictional Expectation to Overcome Societal Addictions. Where Do We Stand? Philos. Manag. 2020, 19, 133-153. [CrossRef]

50. Ward, J.D.; Sutton, P.C.; Werner, A.D.; Costanza, R.; Mohr, S.H.; Simmons, C.T. Is decoupling GDP growth from environmental impact possible? PLoS ONE 2016, 11, 1-14. [CrossRef]

51. Velenturf, A.P.M.; Jopson, J.S. Making the business case for resource recovery. Sci. Total Environ. 2019, 648, 1031-1041. [CrossRef] [PubMed]

52. Jackson, T. Prosperity without Growth? The Transition to a Sustainable Economy; Sustainable Development Commission: London, UK, 2009.

53. Raworth, K. Doughnut Economics: Seven Ways to Think Like a 21st Century Economics; Random House Business Books: London, UK, 2017.

54. Vatn, A. Institutions and the Environment; Edward Elgar Publishing Ltd.: Cheltenham, UK, 2005.

55. Nugent, C. Amsterdam Is Embracing a Radical New Economic Theory to Help Save the Environment. Could It Also Replace Capitalism? TIME, 1 February 2021.

56. Meadows, D.; Randers, J.; Meadows, D. Limits to Growth: The 30-Year Update; Earthscan: London, UK, 2004; ISBN 9781844071449.

57. Kothari, A.; Demaria, F.; Acosta, A. Buen Vivir, Degrowth and Ecological Swaraj: Alternatives to sustainable development and the Green Economy. Development 2014, 57, 362-375. [CrossRef]

58. Schröder, P.; Bengtsson, M.; Cohen, M.; Dewick, P.; Hoffstetter, J.; Sarkis, J. Degrowth within—Aligning circular economy and strong sustainability narratives. Resour. Conserv. Recycl. 2019, 146, 190-191. [CrossRef]

59. Shouten, S. The Doughnut Model for a Fairer, Greener Amsterdam. Green Eur. J. 2020, 1-5. Available online: https://www. greeneuropeanjournal.eu/the-doughnut-model-for-a-fairer-greener-amsterdam/ (accessed on 24 September 2021).

60. Doughnut Economics Action Lab (DEAL); Biomimicry 3.8; Circle Economy; C40 Cities. The Amsterdam City Doughnut: A Tool for Transformative Action; Amsterdam, The Netherlands, 2020. Available online: https:/ /www.circle-economy.com/resources/theamsterdam-city-doughnut-a-tool-for-transformative-action (accessed on 24 September 2021).

61. Ravetz, J.R. Post-Normal Science and the complexity of transitions towards sustainability. Ecol. Complex. 2006, 3, 275-284 [CrossRef]

62. Loorbach, D.; Frantzeskaki, N.; Avelino, F. Sustainability Transitions Research: Transforming Science and Practice for Societal Change. Annu. Rev. Environ. Resour. 2017, 42, 599-626. [CrossRef]

63. Geels, F.W.; Sovacool, B.K.; Schwanen, T.; Sorrell, S. The Socio-Technical Dynamics of Low-Carbon Transitions. Joule 2017, 1, 463-479. [CrossRef]

64. Geels, F.W. A socio-technical analysis of low-carbon transitions: Introducing the multi-level perspective into transport studies. J. Transp. Geogr. 2012, 24, 471-482. [CrossRef]

65. Geels, F.W. The multi-level perspective on sustainability transitions: Responses to seven criticisms. Environ. Innov. Soc. Transitions 2011, 1, 24-40. [CrossRef]

66. Jackson, M.; Lederwasch, A.; Giurco, D. Transitions in theory and practice: Managing metals in the circular economy. Resources 2014, 3, 516-543. [CrossRef]

67. De Jesus, A.; Mendonça, S. Lost in Transition? Drivers and Barriers in the Eco-innovation Road to the Circular Economy. Ecol. Econ. 2018, 145, 75-89. [CrossRef]

68. Baker, S. Sustainable Development; Routledge: London, UK, 2013.

69. Coffey, B. Unpacking the politics of natural capital and economic metaphors in environmental policy discourse. Environ. Politics 2016, 25, 203-222. [CrossRef]

70. Kern, F. Ideas, institutions, and interests: Explaining policy divergence in fostering "system innovations" towards sustainability. Environ. Plan. C Gov. Policy 2011, 29, 1116-1134. [CrossRef]

71. Genus, A.; Theobald, K. Creating low-carbon neighbourhoods: A critical discourse analysis. Eur. Urban Reg. Stud. 2016, 23, 782-797. [CrossRef]

72. Filkov, A.I.; Ngo, T.; Matthews, S.; Telfer, S.; Penman, T.D. Impact of Australia's catastrophic 2019/20 bushfire season on communities and environment. Retrospective analysis and current trends. J. Saf. Sci. Resil. 2020, 1, 44-56. [CrossRef]

73. Environment and Communications References Committee. Never Waste a Crisis: The Waste and Recycling Industry in Australia; Commonwealth of Australia: Canberra \& Sydney, Australia, 2018.

74. Jones, S. Waste management in Australia is an environmental crisis: What needs to change so adaptive governance can help? Sustainability 2020, 12, 9212. [CrossRef]

75. Shooshtarian, S.; Maqsood, T.; Wong, P.S.P.; Khalfan, M.; Yang, R.J. Market development for construction and demolition waste stream in Australia. J. Constr. Eng. Manag. Innov. 2020, 3, 220-231. [CrossRef]

76. Udawatta, N.; Zuo, J.; Chiveralls, K.; Yuan, H.; George, Z.; Elmualim, A. Major Factors Impeding the Implementation of Waste Management in Australian Construction Projects. J. Green Build. 2018, 13, 101-121. [CrossRef]

77. BehaviourWorks. Drivers, Barriers and Interventions That Influence Business Uptake of Circular Economy Approaches; BehaviourWorks: Clayton, Australia, 2019.

78. Brinson, A. The circular economy: International case studies and best practices. J. Proc. R. Soc. New South Wales 2019, $152,82-93$. 
79. Lee, W. Australia's Waste Crisis: Circular Economy Responses to the Contradictions of Capitalism. Master's Thesis, The University of Sydney, Sydney, Australia, 2019. [CrossRef]

80. Commonwealth Government. 2018 National Waste Policy: Less Waste, More Resouces; ACT: Canberra, Australia, 2018.

81. Boxall, N.J.; King, S.; Kaksonen, A.; Bruckard, W.; Roberts, D. Waste Innovation for a Circular Economy: A Summary Report for the CSIRO Cutting Edge Science and Engineering Symposium; CSIRO: Canberra, Australia, 2019.

82. Lyon, A.; Hunter-Jones, P. Critical discourse analysis and the questioning of dominant, hegemonic discourses of sustainable tourism in the Waterberg Biosphere Reserve, South Africa. J. Sustain. Tour. 2019, 27, 974-991. [CrossRef]

83. McKinnon, A. Our Waste Policy is Rubbish: Has Australia's ad-hoc approach to waste management backfired? The Monthly, May 2019. Available online: https:/ / www.themonthly.com.au/issue/2018/may/1525096800/alex-mckinnon/our-waste-policyrubbish (accessed on 13 September 2021).

84. Mclean, L. Can Australia Become the Next Circular Economy Superpower? The Fifth Estate 2019, 10-13. Available online: ecome-the-next-circular-economy-superpower / (accessed on 13 September 2021).

85. ACT Commisioner for Sustainability and the Environment. CIRCULAR_CBR-Unlocking the Potential of a Circular Economy in the $A C T$; Issues Paper; Office of the Commissioner for Sustainability and the Environment: Canberra, Australia, 2019.

86. Green-Industries-SA. Benefits of a Circular Economy in South Australia: Summary; Government of South Australia: Adelaide, Australia, 2017.

87. Loop Circular Economy Platform; VTT Technical Research Centre; Komms-Haus Design \& Communications. Queensland'S Circular Economy Future; Loop Circular Economy Platform: Adelaide, Australia, 2019.

88. Qualitative Research Practice: A Guide for Social Science Students and Researchers; Ritchie, J.; Lewis, J. (Eds.) SAGE Publications: London, UK; Thousand Oaks, CA, USA, 2003.

89. KPMG Economics. Potential Economic Payoff of a Circular Economy; KPMG Economics: 2020. Available online: https://home. $\mathrm{kpmg} / \mathrm{xx} / \mathrm{en} /$ home/insights/2019/04/circular-economy-services.html (accessed on 13 September 2021).

90. Price Waterhouse Cooper. The Road to Circularity: Why a Circular Economy is Becoming the New Normal; Price Waterhouse Cooper: London, UK, 2019.

91. Schandl, H.; King, S.; Walton, A.; Kaksonen, A.; Tapsuwan, S.; Baynes, T. Circular Economy Roadmap for Plastics, Glass, Paper and Tyres-Pathways for Unlocking Future Growth Opportunities for Australia; CSIRO Publishing: Canberra, Australia, 2021; ISBN 9781486314959.

92. Lifecycles; EconSearch; Colby Industries; University of Queensland. Creating Value: The Potential Benefits of a Circular Economy for South Australia; Green Industries SA: Adelaide, Australia, 2017.

93. NSW Government. NSW Circular Economy Policy Statement-Too Good to Waste; NSW Government: Sydney, Australia, 2018 ; p. 9.

94. NSW Circular. The Circular Economy Opportunity; NSW Circular: Sydney, Australia, 2020.

95. Government of Western Australia. Closing the Loop-Waste Reforms for a Circular Economy (Consultation Paper); Government of Western Australia: Perth, Australia, 2020.

96. Regen Melbourne. Towards a Regenerative Melbourne: Embracing Doughnut Economics to Create a New Compass for Melbourne; Regen Melbourne: Melbourne, Australia, 2021.

97. Bimpizas-Pinis, M.; Bozhinovska, E.; Genovese, A.; Lowe, B.; Pansera, M.; Alberich, J.P.; Ramezankhani, M.J. Is efficiency enough for circular economy? Resour. Conserv. Recycl. 2021, 167, 105399. [CrossRef]

98. Holzinger, H. More Efficiency is Not Enough. Capabilities and Limits of the Circular Economy. In The Circular Economy in the European Union; Springer International Publishing: Cham, Switzerland, 2020; pp. 187-206.

99. Fischer, J.; Guy, S. Re-interpreting regulations: Architects as intermediaries for low-carbon buildings. Urban Stud. 2009, 46, 2577-2594. [CrossRef]

100. de Wilde, M.; Spaargaren, G. Designing trust: How strategic intermediaries choreograph homeowners' low-carbon retrofit experience. Build. Res. Inf. 2019, 47, 362-374. [CrossRef]

101. Kivimaa, P.; Boon, W.; Hyysalo, S.; Klerkx, L. Towards a typology of intermediaries in sustainability transitions: A systematic review and a research agenda. Res. Policy 2019, 48, 1062-1075. [CrossRef]

102. Hamann, R.; April, K. On the role and capabilities of collaborative intermediary organisations in urban sustainability transitions. J. Clean. Prod. 2013, 50, 12-21. [CrossRef]

103. Hodson, M.; Marvin, S.; Bulkeley, H. The Intermediary Organisation of Low Carbon Cities: A Comparative Analysis of Transitions in Greater London and Greater Manchester. Urban Stud. 2013, 50, 1403-1422. [CrossRef]

104. van Lente, H.; Hekkert, M.; Smits, R.; van Waveren, B. Roles of Systemic Intermediaries in Transition Processes. Int. J. Innov. Manag. 2003, 07, 247-279. [CrossRef]

105. Yusuf, S. Intermediating knowledge exchange between universities and businesses. Res. Policy 2008, 37, 1167-1174. [CrossRef]

106. Gliedt, T.; Hoicka, C.E.; Jackson, N. Innovation intermediaries accelerating environmental sustainability transitions. J. Clean. Prod. 2018, 174, 1247-1261. [CrossRef]

107. Hyysalo, S.; Juntunen, J.K.; Martiskainen, M. Energy Internet forums as acceleration phase transition intermediaries. Res. Policy 2018, 47, 872-885. [CrossRef]

108. Joosse, S.; Brydges, T. Blogging for Sustainability: The Intermediary Role of Personal Green Blogs in Promoting Sustainability. Environ. Commun. 2018, 12, 686-700. [CrossRef] 
109. Gale, W.F.; Bush, R.E.; Taylor, P.G.; Gouldson, A.; Powell, M.; Bale, C.S.E. The role of intermediaries in low carbon transitionsEmpowering innovations to unlock district heating in the UK. J. Clean. Prod. 2017, 148, 137-147. [CrossRef]

110. Cinner, J.E.; Barnes, M.L. Social Dimensions of Resilience in Social-Ecological Systems. One Earth 2019, 1, 51-56. [CrossRef]

111. van Veelen, B. Caught in the middle? Creating and contesting intermediary spaces in low-carbon transitions. Environ. Plan. C Politics Space 2020, 38, 116-133. [CrossRef]

112. Massey, D.B. For Space; SAGE: London, UK, 2005.

113. Van Weelden, E.; Mugge, R.; Bakker, C. Paving the way towards circular consumption: Exploring consumer acceptance of refurbished mobile phones in the Dutch market. J. Clean. Prod. 2016, 113, 743-754. [CrossRef]

114. Massey, D. Concepts of space and power in theory and in political practice. Doc. d'Analisi Geogr. 2009, 15-26. [CrossRef]

115. Seawright, J.; Gerring, J. Case Selection Techniques in Case Study Research. Political Res. Q. 2008, 61, 294-308. [CrossRef]

116. Briggs, C.L. Learning How to Ask: A Sociolinguistic Appraisal of the Role of the Interview in Social Science Research; Cambridge University Press: Cambridge, UK, 1986; ISBN 9781139165990.

117. Deppermann, A. Interview als Text vs. Interview als Interaktion. Forum Qual. Sozialforsch./Forum Qual. Soc. Res. 2013, 14. [CrossRef]

118. Potter, J.; Hepburn, A. Qualitative interviews in psychology: Problems and possibilities. Qual. Res. Psychol. 2005,2 , $281-307$. [CrossRef]

119. Rapley, T.J. The art(fulness) of open-ended interviewing: Some considerations on analysing interview. Qual. Res. 2001, 1, 303-323. [CrossRef]

120. Roulston, K. Considering quality in qualitative interviewing. Qual. Res. 2010, 10, 199-228. [CrossRef]

121. Holstein, J.; Gubrium, J. The Active Interview in Perspective. In The Active Interview; SAGE Publications, Inc.: Thousand Oaks CA, USA, 1995; pp. 7-18. ISBN 9780803958951.

122. Silverman, D. Interpreting Qualitative Data, 6th ed.; SAGE Publications Ltd.: Los Angeles, CA, USA; London, UK, 2015; Volume 38, ISBN 9781446295434.

123. McCormack, C. Storying stories: A narrative approach to in-depth interview conversations. Int. J. Soc. Res. Methodol. Theory Pract. 2004, 7, 219-236. [CrossRef]

124. Johnston, J.; Szabo, M.; Rodney, A. Good food, good people: Understanding the cultural repertoire of ethical eating. J. Consum. Cult. 2011, 11, 293-318. [CrossRef]

125. Richards, H.; Emslie, C. The "doctor" or the "girl from the University"? Considering the influence of professional roles on qualitative interviewing. Fam. Pract. 2000, 17, 71-75. [CrossRef]

126. Antaki, C. Producing a "cognition". Discourse Stud. 2006, 8, 9-15. [CrossRef]

127. Wetherell, M.; Potter, J. Discourse analysis and the identification of interpretative repertoires. In Analysing Everyday Explanation: A Casebook of Methods; SAGE Publications, Inc.: Thousand Oaks CA, USA, 1988; pp. 168-184.

128. Grinsted, A. Interactive resources used in semi-structured research interviewing. J. Pragmat. 2005, 37, 1015-1035. [CrossRef]

129. Phoenix, A.; Frosh, S.; Pattman, R. Producing Contradictory Masculine Subject Positions: Narratives of Threat, Homophobia and Bullying in 11-14 Year Old Boys. J. Soc. Issues 2003, 59, 179-195. [CrossRef]

130. James, W. Empowering ambiguities. In The Anthropology of Power: Empowerment and Disempowerment in Changing Structures; Routledge Taylor \& Francis Group: New York, NY, USA, 2003; pp. 13-26. ISBN 9780203427057.

131. Alvesson, M.; Karreman, D. Varieties of Discourse: On the Study of Organizations through Discourse Analysis. Hum. Relat. 2000, 53, 1125-1149. [CrossRef]

132. Holland, D.; Lachicotte, W., Jr.; Skinner, D.; Cain, C. Identity and Ageny in Cultural Worlds; Harvard University Press: Cambridge, MA, USA, 1998; ISBN 0674004892.

133. Tozer, L.; Klenk, N. Discourses of carbon neutrality and imaginaries of urban futures. Energy Res. Soc. Sci. 2018, 35, 174-181. [CrossRef]

134. Urrieta, L. Figured worlds and education: An introduction to the special issue. Urban Rev. 2007, 39, 107-116. [CrossRef]

135. Bryman, A. Social Research Methods, 4th ed.; Oxford University Press: Oxford, UK, 2012.

136. Davis, J.; Wolff, H.G.; Forret, M.L.; Sullivan, S.E. Networking via LinkedIn: An examination of usage and career benefits. J. Vocat. Behav. 2020, 118, 103396. [CrossRef]

137. Braun, V.; Clarke, V. Using thematic analysis in psychology. Qual. Res. Psychol. 2006, 3, 77-101. [CrossRef]

138. Garnaut, R. Reset: Restoring Australia after the Pandemic Recession; Blackincbooks: Melbourne, Australia, 2021. 